\title{
Correction: Targeting the angiotensin II type 2 receptor (AT2R) in colorectal liver metastases
}

\author{
Eleanor I Ager*, Way W Chong, Shu-wen Wen, Christopher Christophi
}

\section{Correction}

After publication of this work [1], we noted that we inadvertently failed to properly acknowledge all of our funding agencies. The acknowledgements section has now been modified accordingly.

\begin{abstract}
Acknowledgements
This work was supported by Cancer Australia's Priority-driven Collaborative Cancer Research Scheme and is co-funded by Cancer Australia and Cure Cancer Australia Foundation. We would also like to thank the CanToo fund raisers. Dr Ager is supported by an NHMRC Post-doctoral Training Award. Ms Shu-wen Wen is supported by an Australian Rotary Health Research Fund PhD Scholarship. We would like to thank Professor Mauro Sandrin and his team from the xenotransplantation group at Austin Health (Australia), Dr Russell Hodgson and Claire Lin, for their help with CFSE and PI staining and analysis.
\end{abstract}

Received: 18 October 2010 Accepted: 21 October 2010

Published: 21 October 2010

\section{Reference}

1. Ager IE, Chong WW, Wen SW, Christophi C: Targeting the antiogensin II type 2 receptor (AT2R) in colorectal liver metastases. Cancer Cell Int 2010, 10:19.

doi:10.1186/1475-2867-10-37

Cite this article as: Ager et al:: Correction: Targeting the angiotensin II type 2 receptor (AT2R) in colorectal liver metastases. Cancer Cell

International 2010 10:37.

* Correspondence: eager@unimelb.edu.au

Department of Surgery, The University of Melbourne, Austin Health, Heidelberg, Victoria, Australia

Submit your next manuscript to BioMed Central and take full advantage of:

- Convenient online submission

- Thorough peer review

- No space constraints or color figure charges

- Immediate publication on acceptance

- Inclusion in PubMed, CAS, Scopus and Google Scholar

- Research which is freely available for redistribution
() Biomed Central

\section{Biomed Central}

